Bull. Mater. Sci, Vol. 16, No. 6, December 1993, pp. 693-697. (C) Printed in India.

\title{
X-ray powder diffraction study of $\mathrm{ZnLi}_{0.5} \mathrm{Mn}_{0.5} \mathrm{SnO}_{4}$
}

\author{
SANGEETHA SAMPATH*', M P TARE, R R TRIPATHI and \\ S M TARE

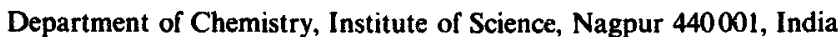 \\ 'Present address: Department of Chemistry, Faculty of Science, M. S. University of Baroda, \\ Baroda 390002 , India \\ MS received 2 January 1993; revised 6 October 1993
}

\begin{abstract}
X-ray crystallographic investigation of the title complex oxide composition reveals the presence of two phases. The first is a spinel phase which is somewhat consistent with $\mathrm{Zn}_{2} \mathrm{SnO}_{4}$ with $a_{0}=8.646 \AA$. The other phase has been identified as a non-spinel phase of $\mathrm{LiMnSnO}_{4}$, the presence of which was confirmed by synthesizing it and comparing its XRD pattern with that of the title composition. The exact composition of the two phases has been determined by intensity calculations. It seems that while cooperative $\mathrm{J}-\mathrm{T}$ effect is responsible for the observed symmetry of $\mathrm{LiMnSnO}_{4}$, the distribution of phase along with separation of phases is attributed to the solubility limit of $\mathrm{Sn}^{4+}$ in such quaternary compositions.
\end{abstract}

Keywords. Spinel phase; $\mathrm{LiMnSnO}_{4}$; intensity calculations; cooperative J-T effect; solubility.

\section{Introduction}

Zinc orthostannate $\mathrm{Zn}_{2} \mathrm{SnO}_{4}$ (Gupta and Mathur 1968; Ioffe et al 1975; Fujita et al 1988), which is a $4: 2$ inverse spinel with cationic distribution $\mathrm{Zn}_{\mathrm{A}}[\mathrm{ZnSn}]_{\mathrm{B}} \mathrm{O}_{4}$, has been widely studied and reported. The ternary derivatives of $\mathrm{Zn}_{2} \mathrm{SnO}_{4}$ cited in literature include $\mathrm{ZnCdSnO}_{4}$ (Panakh-Zade et al 1985), $\mathrm{ZnNiSnO}_{4}$ (Yamaguchi 1953), $\mathrm{ZnCoSnO}_{4}$ (De Strooper 1977), $\mathrm{ZnCuSnO}_{4}$ (Tare et al 1990) and $\mathrm{ZnMgSnO}_{4}$ (Chang and Kaldon 1976). In all these ternary derivatives obtained by substitution of $\mathrm{Zn}^{2+}$ with different divalent ions, the replacement has to occur at B-sites only as the A-sites are occupied by $\mathrm{Zn}^{2+}$ ions with maximum A-site preference energy (Miller 1959). On the other hand, quaternary derivatives of $\mathrm{Zn}_{2} \mathrm{SnO}_{4}$, have not been widely studied. In the present investigation, the $\mathrm{B}$-site $\mathrm{Zn}^{2+}$ ion in $\mathrm{Zn}_{A}[\mathrm{ZnSn}]_{B} \mathrm{O}_{4}$ has been substituted with an equimolar mixture of monovalent and trivalent ions. The monovalent ion chosen here is $\mathrm{Li}^{+}$, the trivalent ion being $\mathrm{Mn}^{3+}$. It is expected that the structural parameters of such a planned quaternary stannate, $\mathrm{ZnLi}_{0.5} \mathrm{Mn}_{0.5} \mathrm{SnO}_{4}$, could be influenced by the covalent nature of $\mathrm{Li}^{+}-\mathrm{Mn}^{3+}$ bond, distortive nature of $\mathrm{Mn}^{3+}$, and the thermodynamic stability of $\mathrm{Sn}^{4+}$ in such a quaternary composition.

\section{Experimental}

Synthesis of the planned composition was carried out by the standard ceramic technique (Economos 1955). The $\mathrm{AR}$ grade oxides $\mathrm{ZnO}, \mathrm{Li}_{2} \mathrm{O}, \mathrm{Mn}_{2} \mathrm{O}_{3}$ and $\mathrm{SnO}_{2}$ were mixed in appropriate molar ratios and fired at 400,600 and $800^{\circ} \mathrm{C}$ for $20 \mathrm{~h}$ each and finally at $1100^{\circ} \mathrm{C}$ for $45 \mathrm{~h}$. Ni-filtered $\mathrm{CuK}_{\alpha}$ was used to obtain the XRD charts.

\footnotetext{
*For correspondence
} 


\section{Results and discussion}

A close observation of the XRD pattern reveals the presence of a predominant spinel phase similar to that of $\mathrm{Zn}_{2} \mathrm{SnO}_{4}$ in addition to a second non-spinel phase (table 1). Hence, to identify and study the nature of second phase, the ASTM data for different constituent oxides and possible oxidic phases were checked and compared with those for this phase. Interestingly, the comparison revealed that the additional lines (non-spinel phase) mostly coincided with those of $\mathrm{SnO}_{2}$. It was logical, therefore, to imagine the possibility of a separation of $\mathrm{SnO}_{2}$. Thus, the observed $\mathrm{SnO}_{2}$ lines were compared with the ASTM data for $\mathrm{SnO}_{2}$. It was observed that though the maximum intensity line ( $d=3.35 \AA$ ) remains the same, the other lines do not obey the exact intensity ratio as referred to in the ASTM data for $\mathrm{SnO}_{2}$. Hence to understand the mode of separation of $\mathrm{SnO}_{2}$ the following scheme was considered:

$$
\begin{aligned}
& \mathrm{Zn}[\mathrm{ZnSn}] \mathrm{O}_{4} \frac{\mathrm{Zn}^{2+} \text { replaced from B-site }}{\text { by } \mathrm{Li}_{0.5}^{+}+\mathrm{Mn}_{0.5}^{3+}} \mathrm{Zn}\left[\mathrm{Li}_{0.5}^{+} \mathrm{Mn}_{0 \cdot 5}^{3+} \mathrm{Sn}\right] \mathrm{O}_{4} \text {. } \\
& \text { (expected composition) }
\end{aligned}
$$

From the observation of the intensities of the lines due to $\mathrm{SnO}_{2}$ phase, it was estimated that about $20 \%$ of $\mathrm{SnO}_{2}$ type phase separates. To confirm the possibility of separation of $\mathrm{SnO}_{2}$, intensity calculations were carried out.

The intensities for non-zero reflections were computed by using the formula

$$
I_{h k l}=\left[F_{h k l}\right]^{2} p \cdot \frac{1+\cos ^{2} 2 \theta}{\cos \theta \sin ^{2} \theta}
$$

\begin{tabular}{|c|c|c|c|}
\hline$I / I$ & $\begin{array}{c}\text { Observed } d \\
(\AA)\end{array}$ & $h k l$ & $\begin{array}{c}\text { Calculated } d \\
(\mathrm{~A})\end{array}$ \\
\hline 13 & 4963 & 111 & 4.990 \\
\hline 17 & $3 \cdot 353^{*}$ & - & - \\
\hline $15 \cdot 5$ & $3-060$ & 220 & 3057 \\
\hline $2 \cdot 3$ & $2.853^{*}$ & - & - \\
\hline 12 & $2.630^{*}$ & - & - \\
\hline 100 & 2.607 & 311 & 2.607 \\
\hline 13 & $2 \cdot 490$ & 222 & 2.496 \\
\hline 4 & $2 \cdot 374^{*}$ & - & - \\
\hline $17 \cdot 3$ & $2 \cdot 161$ & 400 & $2 \cdot 161$ \\
\hline 16 & $1.766^{*}$ & 422 & 1.765 \\
\hline $4 \cdot 5$ & $1.683^{*}$ & - & - \\
\hline 26 & 1.664 & 511,333 & 1.664 \\
\hline 2 & $1.577^{*}$ & - & - \\
\hline 43 & 1.529 & 440 & 1.528 \\
\hline 2 & $1.502^{*}$ & - & - \\
\hline 3.5 & $1.460^{*}$ & - & - \\
\hline $7 \cdot 5$ & $1 \cdot 318^{*}$ & - & - \\
\hline 2.6 & $1 \cdot 209^{*}$ & - & - \\
\hline
\end{tabular}

Table 1. X-ray crystallographic data for $\mathrm{ZnLi}_{0.5}$ $\mathrm{Mn}_{0.5} \mathrm{SnO}_{4}$ (radiation: $\mathrm{CuK}_{a}$ ).

Symmetry: Face centred cubic. $a_{0}=8 \cdot 646 \AA$.

* Second non-spinel phase. 


$$
X R D \text { of } \mathrm{ZnLi}_{0.5} \mathrm{Mn}_{0.5} \mathrm{SnO}_{4}
$$

where $F_{h k l}$ is the structure factor for plane $h k l, p$ the multiplicity of reflection, and last factor $L_{p}=\frac{1+\cos ^{2}(2 \theta)}{\cos \theta \sin ^{2} \theta}$ is the Lorentz polarization factor for the powder method.

The values of atomic scattering factor $f_{r}$ for the different ions, viz. $\mathrm{Zn}^{2+}, \mathrm{Li}^{+}$, $\mathrm{Mn}^{2+}, \mathrm{Mn}^{3+}$ and $\mathrm{Mn}^{4+}$ (Klug and Alexander 1974) and $\mathrm{Sn}^{4+}$ (Umanskago 1961), were used to calculate the structure factor $F_{h k l}$. From the knowledge of $F_{h k l}$ values, intensities for various reflections were calculated.

As the 200, 400 and 422 planes are more sensitive (Azaroff 1968) to the change in cation distribution for spinel structure, intensity ratios $I_{220} / I_{422}$ and $I_{422} / I_{400}$ are compared with the observed intensity ratios for various ionic configurations, from which the site distribution is determined.

Now, for the possibility that $20 \%$ of $\mathrm{SnO}_{2}$ is separating, the following scheme is suggested:

$$
\mathrm{Zn}\left[\mathrm{Li}_{0.5} \mathrm{Mn}_{0.5} \mathrm{Sn}\right] \mathrm{O}_{4} \rightarrow \mathrm{Zn}\left[\mathrm{Li}_{0.5} \mathrm{Mn}_{0.5} \mathrm{Sn}_{0.8}\right] \mathrm{O}_{3 \cdot 6}+0.2 \mathrm{SnO}_{2}\left(20 \% \mathrm{SnO}_{2}\right) .
$$

Equation (1) is nonstoichiometric and even if the quaternary composition was to crystallize in spinel lattice the intensities calculated should substantiate the existence of $\mathrm{Li}_{0.5}, \mathrm{Mn}_{0.5}$ and $\mathrm{Sn}_{0.8}$ in B-site of the lattice, since A-sites are preoccupied by $\mathrm{Zn}^{2+}$. But the intensity calculations for the quaternary composition in (1) do not match with the observed ratios. The second scheme considered to maintain the ratio of ions in A and B sites of spinel structure was the following:

$$
\underset{\text { (A:B ratio 1:1.8) }}{\mathrm{Zn}\left[\mathrm{Li}_{0.5} \mathrm{Mn}_{0.5} \mathrm{Sn}_{0.8}\right] \mathrm{O}_{3.6}} \rightarrow \underset{\text { (A:B ratio 0.9:1.9) }}{\mathrm{Zn}_{0.9}\left[\mathrm{Zn}_{0.1} \mathrm{Li}_{0.5} \mathrm{Mn}_{0.5} \mathrm{Sn}_{0.8}\right] \mathrm{O}_{3.6} .}
$$

However, (2) is also ruled out on the basis of intensity calculations.

It is clear from the above that $\mathrm{SnO}_{2}$ phase is not separating alone. It was considered, therefore, that other ions, viz. $\mathrm{Li}^{+}$and $\mathrm{Mn}^{3+}$, are separating along with $\mathrm{SnO}_{2}$ in equal proportions as shown below:

$$
\begin{aligned}
& \mathrm{Zn}\left[\mathrm{Li}_{0.5} \mathrm{Mn}_{0.5}\right] \mathrm{SnO}_{4} \\
& \text { or } \quad \longrightarrow \mathrm{Zn}_{2} \mathrm{SnO}_{4}+\mathrm{LiMnSnO}_{4} \text {. } \\
& \mathrm{Zn}_{2} \mathrm{LiMnSn}_{2} \mathrm{O}_{8}
\end{aligned}
$$

This envisages the total separation of $\mathrm{LiMnSnO}_{4}$ (non-spinel phase) with the result that the spinel phase must be $\mathrm{Zn}_{2} \mathrm{SnO}_{4}$ alone. To verify this possibility, intensity calculations for $\mathrm{Zn}_{2} \mathrm{SnO}_{4}$ type spinel phase was carried out. It was observed that the intensities of the observed spinel phase do not match with those of $\mathrm{Zn}_{2} \mathrm{SnO}_{4}$ (ASTM), ruling out the possibility of the total separation of $\mathrm{Zn}_{2} \mathrm{SnO}_{4}$ and suggesting the solubility of some $\mathrm{LiMnSnO}_{4}$ in $\mathrm{Zn}_{2} \mathrm{SnO}_{4}$. In other words, the separation of $\mathrm{LiMnSnO}_{4}$ is also not total. But the extent of such a separation is controlled by the solubility of $\mathrm{LiMnSnO}_{4}$ in $\mathrm{Zn}_{2} \mathrm{SnO}_{4}$. The following scheme explains the above contention:

$$
\mathrm{ZnLi}_{0.5} \mathrm{Mn}_{0.5} \mathrm{SnO}_{4} \rightarrow \underset{x\left(\mathrm{LiMnSnO}_{4}\right)+\mathrm{Zn}\left[\mathrm{Li}_{0 \cdot 5-x} \mathrm{Mn}_{0 \cdot 5-x} \mathrm{Sn}_{1-x}\right] \mathrm{O}_{4-4 x} .}{\text { or }}
$$


The ionic distribution in (4) can be expressed in terms of spinel stoichiometry by rearranging as follows:

$$
\begin{aligned}
& \mathrm{Zn}\left[\mathrm{Li}_{0.5-x} \mathrm{Mn}_{0.5-x} \mathrm{Sn}_{1-x}\right] \mathrm{O}_{4-4 x} \rightarrow \\
& \quad \mathrm{Zn}_{1-x}\left[\mathrm{Zn}_{x} \mathrm{Li}_{0.5-x} \mathrm{Mn}_{0.5-x} \mathrm{Sn}_{1-x}\right] \mathrm{O}_{4-4 x}
\end{aligned}
$$

The ionic distribution given above is comparable to that existing in $\mathrm{Zn}_{2} \mathrm{SnO}_{4}$ or $\mathrm{Zn}[\mathrm{ZnSn}] \mathrm{O}_{4}$. Scheme (5) suggests that the value of $x$ should be less than 0.5 and more than 0.2 (computed from $20 \%$ separation of $\mathrm{SnO}_{2}$ type). Hence the intensity calculations were carried out for $0.5>x>0.2$.

The results are summarized in table 2 . It is clear from the table that the distribution is

$$
\mathrm{Zn}_{0.66}\left[\mathrm{Zn}_{0.34} \mathrm{Li}_{0 \cdot 16} \mathrm{Mn}_{0.04}^{2+} \mathrm{Mn}_{0.08}^{3+} \mathrm{Mn}_{0.04}^{4+} \mathrm{Sn}_{0.66}\right] \mathrm{O}_{2 \cdot 64} \text {, }
$$

as there is maximum agreement for this configuration between observed and calculated intensity ratios. It is clear from intensity calculations that the second phase consists of $\mathrm{LiMnSnO}_{4}$ type composition, which is found to crystallize in tetragonal symmetry with $a_{0}=6.748 \AA, c_{0}=10.758 \AA$.

To confirm that the second phase is $\mathrm{LiMnSnO}_{4}$, it was independently synthesized

\begin{tabular}{|c|c|c|c|c|}
\hline \multirow[b]{2}{*}{ Site distribution } & \multicolumn{2}{|c|}{$I_{220} / I_{422}$} & \multicolumn{2}{|c|}{$I_{422} / I_{409}$} \\
\hline & observed & calculated & observed & calculated \\
\hline $\mathrm{Zn}_{0.76}\left(\mathrm{Zn}_{0.24} \mathrm{Li}_{0 \cdot 26} \mathrm{Mn}_{0 \cdot 16}^{3+} \mathrm{Mn}_{0.02}^{2+} \mathrm{Mn}_{0.02}^{4+} \mathrm{Sn}_{0.76}^{4+}\right) \mathrm{O}_{3 \cdot 04}$ & & 2.528 & & $0 \cdot 460$ \\
\hline $\mathrm{Zn}_{0 \cdot 70}\left(\mathrm{Zn}_{0 \cdot 30} \mathrm{Li}_{0 \cdot 20} \mathrm{Mn}_{0 \cdot 12}^{3+} \mathrm{Mn}_{0 \cdot 04}^{2+} \mathrm{Mn}_{0.04}^{4+} \mathrm{Sn}_{0.70}^{4+}\right) \mathrm{O}_{2 \cdot 80}$ & 2.50 & 2.529 & 0.360 & 0.410 \\
\hline $\mathrm{Zn}_{0.68}\left(\mathrm{Zn}_{0.32} \mathrm{Li}_{0.18} \mathrm{Mn}_{0.10}^{3+} \mathrm{Mn}_{0.04}^{2+} \mathrm{Mn}_{0.04}^{4+} \mathrm{Sn}_{0.68}^{4+}\right) \mathrm{O}_{2 \cdot 72}$ & & $2 \cdot 529$ & & 0.401 \\
\hline $\mathrm{Zn}_{0.66}\left(\mathrm{Zn}_{0.34} \mathrm{Li}_{0.16} \mathrm{Mn}_{0.08}^{3+} \mathrm{Mn}_{0.04}^{2+} \mathrm{Mn}_{0.04}^{4+} \mathrm{Sn}_{0.66}^{4+}\right) \mathrm{O}_{2.64}$ & & 2.530 & & $0 \cdot 390$ \\
\hline
\end{tabular}
using AR grade constituent oxides in the proper molar ratio, keeping exactly the

Table 2. Site distribution from intensity ratios in $\mathrm{Zn}_{1-x}\left(\mathrm{Zn}_{x} \mathrm{Li}_{0 \cdot 5-x} \mathrm{Mn}_{0 \cdot 5-x} \mathrm{Sn}_{1-x}\right) \mathrm{O}_{4-4 x}$.

\begin{tabular}{|c|c|c|c|c|c|c|c|}
\hline \multicolumn{4}{|c|}{$\mathrm{LiMnSnO}_{4}$ observed } & \multicolumn{4}{|c|}{$\mathrm{LiMnSnO}_{4}$ synthesized } \\
\hline $\begin{array}{l}d(\text { obs }) \\
(\AA)\end{array}$ & $\begin{array}{c}\boldsymbol{u}(\mathrm{cal}) \\
(\AA)\end{array}$ & $I / I_{0}$ & $h k l$ & $\begin{array}{c}d(\mathrm{obs}) \\
(\AA)\end{array}$ & $\begin{array}{c}d(\mathrm{cal}) \\
(\AA)\end{array}$ & $I / I_{0}$ & $h k l$ \\
\hline 4.960 & 4.800 & 25 & 110 & 4.799 & 4.772 & 51 & 110 \\
\hline 3.353 & 3.374 & 100 & 200 & $3 \cdot 352$ & $3 \cdot 374$ & 100 & 200 \\
\hline 2.853 & 2.858 & 20 & 202 & - & - & - & - \\
\hline $2 \cdot 630$ & 2.632 & 70 & 212 & $2 \cdot 644$ & 2.632 & 80 & 212 \\
\hline $2 \cdot 374$ & $2 \cdot 386$ & 33 & 220 & $2 \cdot 368$ & $2 \cdot 386$ & 28 & 220 \\
\hline 1.766 & 1.767 & 48 & 322 & 1.762 & 1.768 & 71 & 322 \\
\hline 1.683 & 1.687 & 25 & 400 & 1.675 & 1.687 & 18 & 400 \\
\hline 1.577 & 1.574 & 12 & 331 & 1.593 & 1.591 & 15 & 330 \\
\hline 1.502 & 1.499 & 13 & 107 & 1.497 & $1 \cdot 498$ & 15 & 107 \\
\hline 1.460 & 1.463 & 23 & 117 & 1.467 & $1 \cdot 463$ & 7 & 117 \\
\hline $1 \cdot 318$ & $1 \cdot 319$ & 5 & 108 & $1 \cdot 317$ & 1.314 & 7 & 511 \\
\hline 1.209 & 1.209 & 4 & 416 & 1.213 & $1 \cdot 209$ & 11 & 416 \\
\hline
\end{tabular}

Table 3. X-ray diffraction data for $\mathrm{LiMnSnO}_{4}$ observed (as a second phase) and $\mathrm{LiMnSnO}_{4}$ synthesized.

Symmetry, tetragonal; $a_{0} 6.748 \AA$ and $c_{0} 10.758 \AA$. 


$$
X R D \text { of } \mathrm{ZnLi}_{0.5} \mathrm{Mn}_{0.5} \mathrm{SnO}_{4}
$$

same firing schedule. The XRD pattern of this compesition, to our surprise, was almost identical to that of the separated non-spinel phase, confirming that it is due to $\mathrm{LiMnSnO}_{4}$. Table 3 gives the comparison of $\mathrm{LiMnSnO}_{4}$ observed as second phase and $\mathrm{LiMnSnO}_{4}$ synthesized. Thus the quaternary composition $\mathrm{Zn}\left[\mathrm{Li}_{0.5} \mathrm{Mn}_{0.5} \mathrm{Sn}\right] \mathrm{O}_{4}$ from a detailed study of XRD intensities was found to contain the spinel phase, viz.

$$
\mathrm{Zn}_{0.66}\left[\mathrm{Zn}_{0.34} \mathrm{Li}_{0 \cdot 16}^{+} \mathrm{Mn}_{0 \cdot 04}^{2+} \mathrm{Mn}_{0 \cdot 04}^{4+} \mathrm{Mn}_{0 \cdot 08}^{3+} \mathrm{Sn}_{0 \cdot 66}^{4+}\right] \mathrm{O}_{2 \cdot 64} \text {, }
$$

and a non-spinel phase of $\mathrm{LiMnSnO}_{4}$ which can be obtained by substracting the observed spinel composition from $\mathrm{Zn}\left[\mathrm{Li}_{0.5} \mathrm{Mn}_{0.05} \mathrm{Sn}\right] \mathrm{O}_{4}$, i.e. the planned composition, leaving $\mathrm{Li}_{0.34} \mathrm{Mn}_{0.34} \mathrm{Sn}_{0.34} \mathrm{O}_{1 \cdot 36}$ or $\mathrm{LiMnSnO}_{4}$.

\section{Conclusions}

(i) The present investigation reveals that the solubility (Puri et al 1983) of $\mathrm{Sn}^{4+}$ in the quaternary spinel type stannate is around $0.66 \mathrm{~mol}$ per formula unit. This observation is in near-agreement with the reported solubility of $\mathrm{Sn}^{4+}$ in quaternary systems.

(ii) Intensity calculations have been extremely useful to establish the stoichiometry of spinel phase as

$$
\mathrm{Zn}_{0 \cdot 66}\left[\mathrm{Zn}_{0 \cdot 34} \mathrm{Li}_{0 \cdot 16}^{+} \mathrm{Mn}_{0.04}^{2+} \mathrm{Mn}_{0.04}^{4+} \mathrm{Mn}_{0 \cdot 08}^{3+} \mathrm{Sn}_{0 \cdot 66}^{4+}\right] \mathrm{O}_{2 \cdot 64} \text {, }
$$

from which the second phase was identified as $\mathrm{LiMnSnO}_{4}$.

(iii) A close observation of the crystallographic data for $\mathrm{LiMnSnO}_{4}$ showing the lines of $\mathrm{SnO}_{2}$ strongly indicates the solvent action of $\mathrm{SnO}_{2}$ (Tare et al 1990).

(iv) The symmetry and lattice parameters of $\mathrm{LiMnSnO}_{4}$ suggest that $\mathrm{Sn}^{4+}$ and $\mathrm{Mn}^{3+}$ (J-T ion) cooperate to enhance the distortion leading to increasing $c / a$ ratio $(c / a$ for $\mathrm{SnO}_{2}$ is 1.46 and that for $\mathrm{LiMnSnO}_{4}, 1.59$ ). This contention, that the role of $\mathrm{Sn}^{4+}$ to act as a J-T ion along with $\mathrm{Mn}^{3+}$ (in $\mathrm{LiMnSnO}_{4}$ ), receives further support from the fact that the corresponding titanate $\mathrm{LiMnTiO}_{4}$ (Blasse 1963) crystallizes in f.c.c. symmetry, where $\mathrm{Ti}^{4+}$ ion shows no such cooperative $\mathrm{J}-\mathrm{T}$ effect.

\section{References}

Azaroff L V 1968 Elements of X-ray crystallography (New York: McGraw Hill Book Co.)

Blasse G $1963 \mathrm{~J}$. Inorg. Nucl. Chem. 25743

Chang L L Y and Kaldon R C 1976 J. Am. Ceram. Soc. 59275

De Strooper K 1977 Phys. Status Solidi A39 431

Economas G 1955 J. Am. Ceram. Soc. 38341

Fujita K, Kato K and Mitsuzauva S 1988 Nippon Seramikkusu Kyokai Gakujutsu Ronbunshi 966

Gupta M P and Mathur H B 1968 J. Phys. Chem. Solids 291479

Ioffe P A, Baklagin A A and Kozlova V A 1975 Zh. Neorg. Khim. 201712

Klug H P and Alexander L E $1974 X$-ray diffraction procedures for polycrystalline and amorphous materials (New York: John Wiley and Sons) p. 880

Miller A 1959 J. Appl. Phys. 30 Suppl. 24 S

Panakh-Zade S A, Amirdzhanova T B and Kurbanow T Kh 1985 Zh. Neorg. Khim. 302717

Puri R K, Varshney U and Mendiritta R G 1983 Indian J. Pure Appl. Phys. 21686

Tare M P, Tripathi R R, Sampath S and Tare S M 1990 Bull. Mater. Sci. 13191

Umanskago Ya S 1961 Dictionary of X-ray structure analysis of polycrystals (Moscow: Government Publishers of Physico Mathematical Literature) p. 342

Yamaguchi C 1953 Bull. Chem. Soc. Jpn. 26204 